\title{
Kajian tugas dan wewenang kesyahbandaran Pelabuhan Perikanan Pantai (PPP) Tumumpa
}

\author{
Study of tasks and authority of kesyahbandaran at Tumumpa Coastal Fishing Port
}

\author{
Veni S. TURANG*, Mariana E. KAyAdoe, Fransisco P.T. PANGalila dan FrangKy E. KaPARANG \\ Program Studi Pemanfaatan Sumberdaya Perikanan, Fakultas Perikanan Dan Ilmu Kelautan, \\ Universitas Sam Ratulangi, Manado 95115
}

\begin{abstract}
ABSTRAK
Kesyahbandaran main office has an authority to observe enforce the laws of shipping security and safety, and also to coordinate gaverment tasks and authority in harbour. This research was done to know the stakeholders' satisfaction level with the services of syahbandar office at Tumumpa Coastel Fishing Port (PPP), and to identify the problems facing by syahbandar in doing their tasks and authority. Data were collected using questionaries . Data analyzed using a simple statistics of cross were tabulation and histogram. Generlly, tasks and authority of kesyahbandaran have been done very well ask indicited by satisfaction level 4,74 and 4,02 of 5.00 respectifelly. Several identified problems, i.e kesyahbandaran PPP Tumumpa yet had representative office building, radio communcation instrumen is no available yet, and the office does not have a patrol bout.
\end{abstract}

Keywords: syahbandar, coastal fishing port, tumumpa.

\begin{abstract}
Kantor keysahbandaran utama mempunyai tugas melaksanakan pengawasan dan penegakan hukum dibidang keselamatan dan keamanan pelayaran sesuai dengan ketentuan peraturan perundang-undangan, melakukan pemeriksaan surat-surat kapal sebelum berlayar. Penelitian dilakukan untuk meneliti tingkat kepuasan stake holder terhadap pelaksanaan tugas dan wewenang syahbandar di PPP Tumumpa dan mengkaji kendala-kendala yang dihadapi syahbandar dalam pelaksanaan tugas dan wewenang syahbandar. Pengumpulan data dilakukan berdasarkan tanggapan atas pertanyaan-pertanyaan kuesioner. Metode analisis data, menggunakan analisis statistik sederhana dalam bentuk tabulasi silang dan. Tugas dan wewenang sudah dilaksanakan dengan sangat baik yang ditunjukan oleh tingkat kepuasan stake holder dengan nilai masing-masing 4,74, 4,02 dari nilai maksimum 5.00. Beberapa masalah yang teridentifikasi Kesyahbandaran di ppp Tumumpa belum mempunyai gedung perkantoran yang memadai, radio komunikasi belum tersedia dan kantor kesyahbandaran tidak memiliki kapal patroli.
\end{abstract}

Kata-kata kunci: syahbandar, pelabuhan perikanan pantai, tumumpa.

\section{PENDAHULUAN}

Menyadari akan pentingnya peran syahbandar mengenai keselamatan dalam pelayaran, maka lahirlah undang undang nomor 17 tahun 2008 tentang pelayaran, berbagai macam peraturan telah mendahului peraturan perundang undangan ini, dilihat dari konteks sejarah tentang perkembangan tugas dan wewenang syahbandar dalam pelabuhan telah mengalami perbaikan-perbaikan dan peningkatan yang akan mengangkat lebih jelas mengenai peran yang sangat penting bagi kesyahbandaran.

Pelabuhan perikanan sebagai penyedia fasilitas operasional kapal-kapal perikanan memiliki peran yang cukup signifikan dalam mendukung kegiatan peningkatan perikanan laut. Sehingga keberadaan pelabuhan perikanan perlu mendapat perhatian khusus dalam pengembangan dan implementasi peran sebagai penyedia fasilitas pokok kegiatan penangkapan perikanan laut. Dengan demikian

\footnotetext{
*Penulis untuk penyuratan; email: Veniturang42@gmail.com
} 
setiap kapal perikanan yang akan berlayar baik untuk melakukan proses penangkapan ikan, maupun proses pengangkutan ikan harus memiliki dokumen-dokumen yang tersirat dalam undangundang No 45 tahun 2009 guna mendukung kelancaran proses penangkapan maupun pengangkutan ikan agar di kemudian hari tidak terdapat kecelakaan atau hambatan di tengah kegiatan penangkapan ikan dikarenakan keberangkatan kapal perikanan yang tidak memenuhi syarat dan tetap memaksakan untuk melakukan kegiatan penangkapan ikan.

Syahbandar berkewenanangan mengeluarkan Surat Perintah Berlayar (SPB) sesuai aturan hukum masing masing, untuk Syahbandar di Pelabuhan Perikanan yang merupakan personil Pelabuhan Perikanan Ditjen Perikanan Tangkap Kementerian Kelautan dan Perikanan menggunakan dasar Undang-Undang :

1. Undang-Undang No. 31 Tahun 2004 tentang Perikanan sebagaimana telah diubah dengan UU No. 45 tahun 2009 tentang perubahan atas UU No. 31 tentang Perikanan

2. Undang-Undang No. 17 Tahun 2008 tentang Pelayaran

3. Peraturan Pemerintah No. 7 Tahun 2000 tentang Kepelautan

4. Peraturan Pemerintah No. 69 Tahun 2001 tentang Kepelabuhanan

5. Peraturan Pemerintah No. 51 Tahun 2002 tentang Perkapalan

6. Peraturan Menteri Perhubungan No. 46 Tahun 1996 tentang Sertifikasi Kelaiklautan Kapal Penangkap Ikan

7. Peraturan Menteri Kelautan dan Perikanan No. PER.08/MEN/2012 tentang Kepelabuhanan Perikanan

8. Peraturan Menteri Kelautan dan Perikanan No. 30/MEN/2012 tentang Usaha Perikanan Tangkap di Wilayah Pengelolaan Perikanan Negara Republik Indonesia

9. Peraturan Menteri Kelautan dan Perikanan No. 3/PERMEN-KP/2013 tentang Kesyahbandaran di Pelabuhan Perikanan

10. Keputusan Menteri Perhubungan No. KM 01 tahun 2010 tentang Tata Cara Penerbitan Surat Persetujuan Berlayar (Port Clearence)

11. Keputusan Menteri Kelautan dan Perikanan No. KEP.19/MEN/2006 tentang Pengangkatan Syahbandar di Pelabuhan Perikanan sebagaimana telah diubah terakhir dengan Keputusan Menteri Kelautan dan Perikanan KEP.48/MEN/2009
12. Keputusan Menteri Kelautan dan Perikanan No. KEP.06/MEN/2010 tentang Alat Penangkapan Ikan di WPPNRI

13. Keputusan Menteri Perhubungan No. SK.284 Tahun 2011 tentang Pengangkatan Syahbandar di Pelabuhan Perikanan

14. Keputusan Menteri Kelautan dan Perikanan No. KEP.01/MEN-DJPT/2011 tentang Penempatan Petugas Syahbandar di Pelabuhan Perikanan

15. Keputusan Menteri Kelautan dan Perikanan No. KEP.01/MEN-DJPT/2012 tentang Penempatan Syahbandar di Pelabuhan Perikanan

16. Keputusan Dirjen Perikanan Tangkap No. KEP.31/DJ-PT/2012 tentang Petunjuk Pelaksanaan Surat Persetujuan Berlayar Kapal Perikanan.

Berdasarkan latar belakang, maka permasalahan pokok yang dikaji dalam penelitian ini adalah Apakah pelayanan kesyahbandaran sesuai dengan : (1) Undang-Undang No. 45 tahun 2009 pasal 42 ayat 2 yang menguraikan tugas dan kewenangan syahbandar di pelabuhan perikanan Setiap kapal perikanan yang akan berlayar dari pelabuhan perikanan wajib memiliki surat izin berlayar kapal perikanan yang di keluarkan oleh syahbandar, (2) Kalau sudah dilaksanakan atau belum masalahnya apa.

\section{METODE PENELITIAN}

Penelitian ini merupakan penelitian deskriptif dengan pendekatan survei. Metode deskriptif adalah suatu metode dalam meneliti status sekelompok manusia,suatu objek,suatu set kondisi, suatu sistem pemikiran ataupun suatu kelas peristiwa pada masa sekarang. Tujuan dari penelitian deskriptif ini adalah untuk membuat deskripsi, gambaran atau lukisan secara sistematis, faktual dan akurat mengenai fakta-fakta, sifat-sifat sberta hubungan antar fenomena yang diselidiki. Teknik pengambilan data dilakukan dengan kuesioner yang terdapat 20 pertanyaan dan masingmasing pertanyaan diberi skoring, Dalam penelitian ini penulis mengambil sampel Petugas Syabandar, Nahkoda, dan ABK dengan profil responden dapat dilihat pada tabel 1 .

Untuk mengetahui gambaran kerja Petugas Syahbandar digunakan analisis deskriptif berdasarkan tanggapan atas pertanyaan- 
pertanyaan kuesioner Kategori Presentasi, $1=$ sangat tidak puas, $2=$ tidak puas, $3=$ cukup puas, $4=$ puas, $5=$ sangat puas .

Tabel 1. Profil Responden

\begin{tabular}{llr}
\hline Kriteria & Sub Kriteria & Jumlah \\
& & \\
\hline Jenis Kelamin & Laki-laki & 19 \\
& Perempuan & 1 \\
Pekerjaan & Petugas Syahbandar & 4 \\
Responden & Nahkoda & 11 \\
& Abk & 5 \\
\hline
\end{tabular}

\section{HASIL DAN PEMBAHASAN}

Syahbandar suatu instansi yang dibentuk oleh pemerintah untuk melakukan pengawasan pada setiap kapal yang memasuki pelabuhan dan selama berada di pelabuhan wajib mematuhi peraturanperaturan untuk menjaga ketertiban dan kelancaran lalu lintas kapal di pelabuhan, serta sebagai pihak yang memberikan ijin kepada setiap kapal yang akan berlayar karena kapal tersebut wajib memiliki Surat Izin Berlayar yang dikeluarkan oleh syahbandar setelah memenuhi persyaratan kelaiklautan kapal.

Syahbandar adalah seorang pejabat ahli yang menentukan kelaikan kapal dan sangat terkait dengan keselamatan pelayaran, untuk itu syahbandar di Pelabuhan Perikanan adalah syahbandar yang ditunjuk dalam rangka keselamatan pelayaran.

Pemberitahuan rencana kedatangan dari nakhoda atau pemilik kapal atau penanggung jawab perusahaan. dan disampaikan paling lama 48 jam bagi kapal perikanan berbendera asing atau 2 jam bagi kapal perikanan berbendera Indonesia sebelum kapal perikanan memasuki pelabuhan perikanan. Pemberitahuan rencana kedatangan dapat dilakukan secara langsung kepada Syahbandar di Pelabuhan Perikanan atau melalui radio komunikasi Syahbandar di Pelabuhan Perikanan menyiapkan tempat tambat labuh Serta menerbitkan surat tanda bukti lapor kedatangan kapal perikanan setelah dokumen kapal perikanan dinyatakan lengkap dan sah.

Syahbandar di Pelabuhan Perikanan mengatur keberangkatan kapal perikanan berdasarkan pemberitahuan rencana keberangkatan kapal perikanan dari nakhoda atau pemilik kapal atau penanggung jawab perusahaan pemberitahuan rencana keberangkatan kapal perikanan kepada
Syahbandar di Pelabuhan Perikanan ini dilakukan dengan mengajukan surat pemberitahuan rencana keberangkatan kapal perikanan. Pemberitahuan ini paling lama 24 (dua puluh empat) jam bagi kapal perikanan berbendera asing atau 2 (dua) jam bagi kapal perikanan berbendera Indonesia sebelum kapal perikanan meninggalkan pelabuhan perikanan.

Syahbandar di Pelabuhan perikanan menerbitkan surat tanda bukti lapor keberangkatan kapal perikanan setelah nakhoda menyerahkan dokumen kapal perikanan dan dinyatakan lengkap dan sah.

Definisi dari Surat Persetujuan Berlayar itu sendiri adalah Dokumen Negara yang dikeluarkan oleh Syahbandar kepada setiap kapal yang akan berlayar meninggalkan pelabuhan setelah kapal memenuhi persyaratan kelaiklautan kapal dan kewajiban lainnya.

Berdasarkan deskripsi frekuensi dapat didefinisikan tanggapan responden terhadap item-item pertanyaan variable tugas dan wewenang syahbandar sebagai berikut :

Responden menilai terhadap pertanyaan No.1: petugas syahbandar mengawasi kelaiklautan kapal, keselamatan, keamanan dan ketertiban di pelabuhan? sebagian responden menyatakan baik $(4,7)$, dengan skor nilai 94 termasuk dalam kategori baik. Artinya menurut penilaian responden petugas syahbandar sudah mengawasi kelaiklautan kapal, keselamatan, keamanan dan ketertiban di pelabuhan dengan baik.

Responden menilai terhadap pertanyaan No.2: petugas syahbandar mengawasi tertib lalu lintas kapal di perairan pelabuhan dan alur pelayaran? sebagian responden menyatakan baik $(4,25)$, dengan skor nilai 85 termasuk dalam kategori baik. Artinya menurut penilaian responden petugas syahbandar sudah mengawasi tertib lalu lintas kapal di perairan pelabuhan dan alur pelayaran dengan baik.

Responden menilai terhadap pertanyaan No.3: petugas syahbandar mengawasi kegiatan alih muat di perairan pelabuhan? sebagian responden menyatakan cukup baik $(3,7)$, dengan skor nilai 74 termasuk dalam kategori cukup baik. Artinya menurut penilaian responden petugas syahbandar mengawasi kegiatan alih muat di perairan pelabuhan dengan cukup baik.

Responden menilai terhadap pertanyaan No.4: petugas syahbandar memeriksa log book penangkapan ikan? sebagian responden menyatakan sangat setuju (5), dengan skor nilai 100 
termasuk dalam kategori sangat baik. Artinya menurut penilaian responden, petugas syahbandar sudah memeriksa log book penangkapan ikan dengan sangat baik.

Responden menilai terhadap pertanyaan No.5: petugas syahbandar mengawasi kegiatan penundaan kapal? sebagian responden menyatakan cukup baik $(3,8)$, dengan skor nilai 76 termasuk dalam kategori cukup baik. Artinya menurut penilaian responden petugas syahbandar mengawasi kegiatan penundaan kapal dengan cukup baik.

Responden menilai terhadap pertanyaan No.6: petugas syahbandar mengawasi pengisian bahan bakar? sebagian responden menyatakan cukup baik $(3,3)$, dengan skor nilai 66 termasuk dalam kategori cukup baik. Artinya menurut penilaian responden petugas syahbandar mengawasi pengisian bahan bakar dengan cukup baik.

Responden menilai terhadap pertanyaan No.7: petugas syahbandar mengawasi pembangunan fasilitas pelabuhan? sebagian responden menyatakan baik (4), dengan skor 60 termasuk dalam kategori baik. Artinya menurut penilaian responden petugas syahbandar mengawasi pembangunan fasilitas pelabuhan dengan baik.

Responden menilai terhadap pertanyaan No.8: petugas syahbandar melaksanakan bantuan pencarian dan penyelamaan sudah? sebagian responden menyatakan baik $(4,5)$, dengan skor 90 termasuk dalam kategori baik. Artinya menurut penilaian responden petugas syahbandar melaksanakan bantuan petncarian dan penyelamatan dengan baik.

Responden menilai terhadap pertanyaan No.9: petugas syahbandar mengkoordinasikan seluruh kegiatan pemerintahan di pelabuhan? sebagian responden menyatakan baik $(4,35)$, dengan skor 87 termasuk dalam kategori baik. Artinya menurut penilaian responden petugas syahbandar mengkoordinasikan seluruh kegiatan pemerintahan di pelabuhan dengan baik.

Responden menilai terhadap pertanyaan No.10: petugas syahbandar memeriksa dan menyimpan surat, dokumen, dan warta kapal? sebagian responden menyatakan baik $(4,2)$, dengan skor 84 termasuk dalam kategori baik. Artinya menurut penialaian responden petugas syahbandar memeriksa dan menyimpan surat, dokumen, dan warta kapal dengan baik.

Secara umum tugas kesyahbandaran terhadap kapal-kapal perikanan di Pelabuhan Perikanan
Pantai Tumumpa sudah di laksanakan dengan baik (kumulatif rata-rata $=4,74$ ).

Responden menilai terhadap pertanyaan No.11: petugas syahbandar menerbitkan persetujuan kegiatan kapal di pelabuhan? sebagian responden menyatakan baik $(4,35)$, dengan skor 87 termasuk dalam kategori baik. Artinya menurut penilaian responden petugas syahbandar menerbitkan persetujuan kegiatan kapal di pelabuhan dengan baik.

Responden menilai terhadap pertanyaan No.12: petugas syahbandar melakukan pemeriksaan kapal? sebagian responden menyatakan baik $(4,85)$, dengan skor 97 termasuk dalam kategori baik. Artinya menurut penilaian responden petugas syahbandar sudah melakukan pemeriksaan kapal dengan baik.

Responden menilai terhadap pertanyaan No.13: apakah petugas syahbandar menerbitkan surat persetujuan berlayar? sebagian responden menyatakan baik $(4,95)$, dengan skor 99 termasuk dalam kategori baik. Artinya menurut penilaian responden, petugas syahbandar menerbitkan surat persetujuan dengan baik.

Responden menilai terhadap pertanyaan No.14: apakah petugas syahbandar melakukan pemeriksaan kecelakaan kapal rata-rata? sebagian responden menyatakan cukup baik $(3,6)$, dengan skor 72 termasuk dalam kategori cukup baik. Artinya menurut penilaian responden, petugas syahbandar sudah melakukan pemerikasaan kecelakaan kapal tapi lebih banyak diambil alih oleh (Polairud) Polisi Air dan Udara.

Responden menilai terhadap pertanyaan No.15: apakah petugas syahbandar mengawasi sijil awak kapal? sebagian responden menyatakan baik (4.65), dengan skor 93 termasuk dalam kategori baik. Artinya menurut penilaian responden petugas syahbandar sudah mengawasi sijil awak kapal dengan baik.

Responden menilai terhadap pertanyaan No.16: apakah terbatasnya personil syahbandar perikanan yang bertugas di pelabuhanperikanan merupakan suatu kendala? sebagian responden menyatakan cukup baik $(3,85)$, dengan skkor 77 termasuk dalam kategori cukup baik. Artinya menurut penilaian responden, terbatasnya personil syahbandar merupakan suatu kendala karena masing-masing petugas syahbandar sudah mempunyai tugas yang harus mereka kerjakan tapi karena terbatasnya personil syahbandar banyak yang sudah mengerjakan pekerjaan yang bukan tugasnya. 
Responden menilai terhadap pertanyaan No.17: apakah penyedia fasilitas dan kebutuhan melaut telah memenuhi kebutuhan nelayan? sebagian responden menilai cukup baik $(3,8)$, dengan skor 78 termasuk dalam kategori cukup baik. Artinya menurut penilain responden, penyedia fasilitas dan kebutuhan melaut belum memenuhi kebutuhan nelayan contohnya bolder untuk menambatkan kapal masih kurang sekali sebagian kapal kurang megikatkan tali di batu yang besar.

Responden menilai terhadap pertanyaan No.18: apakah nahkoda bisa berlayar jika hanya mempunyai surat izin penangkapan ikan (SIPI) sedangkan dia tidak memiliki surat izin usaha perikanan (SIUP)? semua responden menyatakan tidak baik (1), dengan skor 100 termasuk dalam kategori tidak baik. Artinya menurut penilain responden Surat Izin Penangkapan Ikan (SIPI) harus dimiliki setiap kapal perikanan untuk melakukan kegiatan penangkapan ikan dan tidak terpisahkan dengan Surat Izin Usaha Perikanan (SIUP).

Responden menilai terhadap pertanyaan No.19: apakah surat persetujuan berlayar hanya dapat digunakan untuk 1 kali pelayaran? semua responden menyatakan sangat baik (5), dengan skor 100 termasuk dalam kategori sangat baik. Artinya menurut penilaian responden, surat persetujuan berlayar hanya dapat digunakan 1 kali pelayaran.

Responden menilai terhadap pertanyaan No.20: apakah petugas syahbandar sudah melakukan penegakan hukum dibidang keselamatan dan keamanan pelayaran sesuai dengan ketentuan peraturan perundang-undangan? sebagian responden menyatakan baik $(4,45)$, dengan skor 89 termasuk dalam kategori baik. Artinya menurut penilain responden, petugas syahbandar sudah melakukan penegakan hukum dibidang keselamatan dan keamanan pelayaran sesuai dengan ketentuan perundang-undangan dengan baik.

Secara umum wewenang kesyahbandaran terhadap kapal-kapal perikanan dipelabuhan pantai tumumpa sudah dilaksanakan dengan baik (kumulatif rata-rata $=4,025$ )

Secara umum tugas dan wewenang petugas syahbandar di nilai responden dengan rata-rata 4,16 yang berarti di nilai baik. Hal ini juga penyebaran skornya jelas terlihat pada gambar berikut ini :

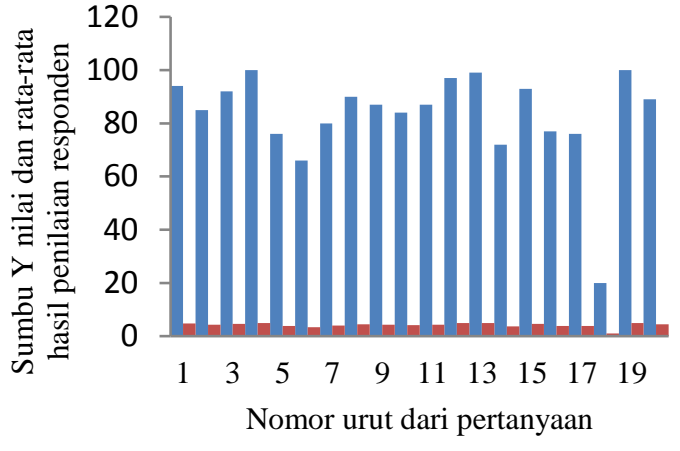

Sumber : Data Hasil Kuesioner_PPP Tumumpa 2018.

Gambar 1: Grafik penyebaran skor responden

Tabel 2. Kekurangan Dan Kendala Syahbandar

\begin{tabular}{clll}
\hline No & $\begin{array}{l}\text { Tujuan } \\
\text { syahbandar }\end{array}$ & Tercapai/belum & Kendala \\
\hline 1 & $\begin{array}{l}\text { Kantor Khusus } \\
\text { Kesyahbandaran }\end{array}$ & Belum & Anggaran \\
2 & Alat komunikasi & Belum & Anggaran \\
3 & Kapal Patroli & Belum & Anggaran \\
\hline
\end{tabular}

\section{KESIMPULAN}

Secara umum tugas kesyahbandaran terhadap kapal-kapal perikanan di Pelabuhan Perikanan Pantai Tumumpa sudah di laksanakan dengan baik (kumulatif rata-rata $=4,74$ ). Secara umum wewenang kesyahbandaran terhadap kapal-kapal perikanan di Pelabuhan Perikanan Pantai Tumumpa sudah di laksanakan dengan baik (kumulatif ratarata $=4,025$ ).

Kantor syahbandar belum tersedia dan sampai saat ini masih digabung dengan kantor pengolahan hasil perikanan. Alat komunikasi/radio khususnya dikantor juga belum tersedia, termasuk kapal patroli. Kendala-kendala ini disebabkan masih menunggu anggaran dari pemerintah untuk pengadaannya.

\section{DAFTAR PUSTAKA}

Direktorat Jenderal Perikanan, 1994. Fungsi dari pelabuhan perikanan.

Lubis E. 2012. Pelabuhan Perikanan. Bogor: IPB Press. 197 hlm.

Gultom, E, 2009. Hukum Pengangkutan Laut, Literata Lintas Media,Jakarta.

Iman Syahputra Tunggal, 1997. Peraturan Perundangundangan Pelayaran dan Penerbangan di Indonesia, Hamarindo, Jakarta. 
KKP, 2006. Pengangkatan Syahbandar di Pelabuhan Perikanan. Keputusan Menteri Kelautan dan Perikanan Republik Indonesia. KEP.19/MEN/2006.

KKP, 2013. Kesyahbandaran di Pelabuhan Perikanan. Peraturan Menteri Kelautandan Perikanan Republik Indonesia. Peraturan Pemerintah No.3/PERMEN .KP/2013 Pasal 32.

Lasse, 2014, Keselamatan Pelayaran Di Lingkungan Teritorial Pelabuhan dan Pemanduan Kapal, Jakarta.

Nikodemus Kirwelakubun, 2017, Analisis Pelayanan Bongkar Muat Di Pelabuhan Perikanan Pantai (PPP) Tumumpa Di Kota Manado
Peraturan Menteri Kelautan dan Perikanan Nomor: PER.16/MEN/2006 tentang Pelabuhan Perikanan.

Randy Y.C. 2013. Tanggung Jawab Syahbandar Dalam Keselamatan Pelayaran ditinjau dari UU Pelayaran No. 17 Tahun 2008 Tentang Pelayaran. Lex Administratum, Vol.I/No.1/Jan-Mrt/2013

Undang-undang Republik Indonesia No 31 tahun 2004. Tentang perikanan.

Undang-undang Republik Indonesia No 45 tahun 2009. Tentang perikanan.

Veni Turang, 2016, Kelengkapan Dokumen Tiba Berangkat Kapal Perikanan Menurut Peraturan Kesyahbandaran Di Pelabuhan Perikanan 